\title{
An exploration of gender equity in household: A case from a peatland- based community in Riau, Indonesia
}

\author{
TUTI HERAWATI ${ }^{1,2,}$, DEDE ROHADI ${ }^{2}$, MAMAT RAHMAT ${ }^{3}$, BONDAN WINARNO ${ }^{3}$ \\ ${ }^{1}$ Centre for Socio-Economy, Policy and Climate Change, Forestry Research Development and Innovation Agency, Ministry of Environment and Forestry, \\ Jl. Gunung Batu No.5. Bogor 1611, West Java, Indonesia. Tel./fax. +62-251-8633944, `email: tuti_hera_wati@yahoo.com \\ ${ }^{2}$ Centre for International Forestry Research. Jl. Cifor, Situ Gede, Bogor 16115, West Java, Indonesia \\ ${ }^{3}$ Forestry Research Centre Palembang. Jl. Kol. H. Burlian Km. 6 No.5, Palembang 30961, South Sumatra, Indonesia.
}

Manuscript received: 20 December 2018. Revision accepted: 26 February 2019.

\begin{abstract}
Herawati T, Rohadi D, Rahmat M, Winarno B. 2019. An exploration of gender equity in household: A case from a peatlandbased community in Riau, Indonesia. Biodiversitas 20: 853-861. Gender roles in peatland-based communities' livelihoods are an important factor in livelihood vulnerability due to challenging characteristics for conducting agriculture in this area. This article reports on a study of gender roles in Riau Province in 7 villages in 3 districts, aiming to identify significant attributes that determining gender equity at the household level. The data was collected through structured interviews in 221 households, in-depth interviews and Focus Group Discussions in every village. The research indicated that gender roles in agricultural activities are significantly dominated by men, while women play a more significant role in domestic activities. Both men and women contribute equally in the social life of the community; women's participation and group membership is equal to men's. Poor families tend to have higher gender equity in agricultural activities than rich households. The role of women in wealthier households is not in their physical contribution on the land but is mostly transformed into a decision making role. This indicates that women have a significant role in family livelihoods for both poor and rich families, but in different forms.
\end{abstract}

Keywords: Access, benefit, gender role, livelihood, peatland

\section{INTRODUCTION}

Peatlands and people are connected by a long history of cultural development (Parish et al. 2008; Maftuah et al. 2015; Renou-Wilson 2018). Humans have directly utilized peatlands for thousands of years (Renou-Wilson 2018; Koglo et al. 2019), leading to differing and varying degrees of impact (Tooth 2018; Strack et al. 2018). Some peatlands worldwide have been used in agriculture (Yu et al. 2018), for grazing (Noble et al. 2018) and for growing crops (Kandel et al. 2013). Large areas of tropical peatlands have in recent years been cleared and drained (Rival 2018; Schoneveld et al. 2018). Peat is being extracted for industrial and domestic fuel, as well as for use in horticulture and gardening (Parish et al. 2008; Schoneveld et al. 2018). Local people traditionally benefit from peat swamp forests for timber to build their houses, nutrient-rich wild food and fish to supplement their diet, clean water and access to medicinal plants (Gunawan 2018). These natural riches can also be a source of income and well-being (Hergoualc'h et al. 2018).

Referring to peatlands' biophysical characteristics, agricultural activities in peatlands are very challenging due to the need for more complicated treatments and low productivity (Worrall et al. 2010). Another reason that peat is a non-renewable natural resource (Maftuah et al. 2015) is that the use of peatlands for agriculture has always been under debate. Communities who depend on peatlands are significantly affected by such debates as the possible alternative solutions will influence their livelihoods' practices.

A study by the Food and Agriculture Organization of United Nations argued that building livelihood resilience will require gender mainstreaming as a key strategy (FAO 2016). Gender mainstreaming is not an end, but a means to the goal of gender equity (Hannan 2000). The first steps in the mainstreaming strategy is an assessment of how and why gender differences and inequalities are relevant to the subject under discussion, identifying where there are opportunities to narrow these inequalities and deciding on the approach to be taken. Tracing back in time, the journey of gender research reveals that until the 1970s, as Rudyard Kipling's Jungle Book argued, women have been to a great extent missing from research on farming, animal husbandry, and forestry. Ester Boserup's study in 1970, Women's Role in Economic Development, played a milestone job in featuring women's key but invisible role in agricultural production. From that point forward an extensive range of publications make visible women's crucial contributions to productive and reproductive work within and beyond the household (Asher and Varley 2018). A systematic literature review by Colfer et al. (2015) also identified 670 papers discussing gender and forestry but not including more recent papers, such as Prasetyo et al. 2018; Arwida et al. 2016; Elias et al. 2018; Broeckhoven and Cliquet 2015. There has been limited literature on gender in Indonesia (Maharani et al. 2018). Moreover, it is still a paradox that there have been abundant studies on gender on the one hand and peatland 
studies in the other, but still research on peatland that also considering the gender aspect is non-existent

Motivated by the lack of knowledge on gender in peatland management, this study aims to examine gender roles in peatland-based communities by identifying 1) How gender roles are distributed on productive, reproductive, and social activities, 2) Is there equity in the distribution of assets and benefit sharing; and 3) Is there any correlation between gender equity and level of household welfare? The paper will test the hypothesis that gender roles tend to be more equal in better-off households. Understanding gender roles will contribute to more effective management of peatlands as to support local livelihoods and a mean on holistic assessment of justice and equity in REDD ${ }^{+}$ initiatives (Schroeder and McDermott 2014; VisserenHamakers et al. 2012; McDermott 2013). According to FAO (2016), reducing gender inequality is the best way to end hunger and contribute to global concerns about ecology. More specifically as convinced by Djoudi et al. (2016), it relates to climate change adaptation strategy.

\section{MATERIALS AND METHODS}

\section{Study area}

The study was conducted in 2016-2018 in Riau Province through an IFAD-funded research project, Haze Free Sustainable Livelihoods (HFSL). The selected project area is Sungai Kampar-Sungai Indragiri Peatland Hydrological Unit (SKI PHU) that covers about 850,000 hectares $\left(8,500 \mathrm{~km}^{2}\right)$. It includes about $5 \%$ of the nation's peatlands and $20 \%$ of Riau's peatland areas. The project area is part of the three administrative districts of Indragiri Hilir (approximately 50\% of the SKI PHU); Indragiri Hulu (30\%); and Pelalawan (20\%). Target villages are most of the villages nearest to Kerumutan Wildlife Reserve, including: Teluk Meranti, (Pelalawan District); Redang, Sialang Dua Dahan, Tanjung Sari, (Indrigiri Hulu District); and Bayas Jaya, Simpang Gaung, Teluk Kabung (Indrigiri Hilir District) (Figure 1). Two of the villages i.e Tanjungsari and Bayas Jaya are transmigrant settlements, established by the central government. The main ethnic groups of Riau are Malay (indigenous to Riau, 33.0\%), Javanese (indigenous to Java, 30.4\%), Batak (indigenous to North Sumatra, 12.5\%), and Minang (indigenous to West Sumatra, 12.2\%) (Na'im and Syaputra 2011).

Riau is located on the Straits of Malacca - near to significant markets in Malaysia and Singapore - and south of North Sumatra, where Indonesia's estate horticulture initially developed in the late 19th century under Dutch imperialism (Budidarsono et al. 2013). With Riau's comparatively low population density and the abundance of cheap and 'empty' agro-ecologically suitable land, towards the latter end of the 20th century many oil palm producers in pursuit of new land began to migrate from North Sumatra to Riau. Riau had overtaken North Sumatra as the largest oil palm producing province in Indonesia by 1999 (World Bank 2014). Riau accounts for an estimated 22.8\% of Indonesia's total mature oil palm acreage and $30.3 \%$ of Indonesian oil palm smallholders. Of the 2.46 million ha of land under oil palm cultivation in Riau, $58.6 \%$ is officially classified as being under smallholder oil palm cultivations, with only $3.6 \%$ and $37.8 \%$ cultivated by state-owned and private companies, respectively (DJP 2015).

\section{Procedures}

Theoretical framework

Gender is best described as a dynamic organizing principle in society. It is more than an individual's biological sex (male/female) (FAO 2009; RECOFTC 2015). Gender is a learned pattern of behavior that is embedded in everything we do at the individual, community, and institutional levels (Kuehnast et al. 2018). The observed characteristics of women's position in agriculture are central to the Harvard Analytical Framework (RECOFTC 2015). This framework was one of the first to be used in undertaking gender analyses of smallholder farm families and has since become common in natural resource programmes and is even sometimes referred to as 'the' framework for gender analysis (Razavi and Miller 1995; Mulyotami et al. 2013; Villamor GB 2015; RECOFTC 2016).

The Harvard Analytical Framework addresses the question of 'who does what'. The survey was conducted to determine gender-specific roles in livelihood activities for all productive, reproductive, and community tasks. Our study developed a profile of gender roles distribution in the households of peatland dependent communities living adjacent to a protected area. Modifying the Harvard framework, we examined four aspects of gender role distribution in more detail: (i) productive or agricultural activities on peatland areas; (ii) reproductive or managing in household affairs; (iii) community roles or activities in social life; and (iv) benefits and assets distribution between men and women in each household (Table 1).

\section{Data collection}

A mix of qualitative and quantitative data was collected from focus group discussions (FGDs), key informant interviews (KIIs) and semi-structured household surveys. The qualitative data was collected through FGDs and KIIs, while quantitative data was obtained from respondent household interviews. We selected household respondents based on participants' assessments (during the FGDs) of community members' wealth status (poor, moderate and rich). The criteria for determining this wealth category were agreed in the discussions, considering ownership of agricultural land, type of housing, vehicle or other household asset ownership, and non-agricultural income. Each group category between the poor, medium and rich household was represented in balanced numbers, with an average of 30 households from every village. FGD participants identified community members who were in accordance with each of the group criteria and came up with 30-40 candidate respondents. 

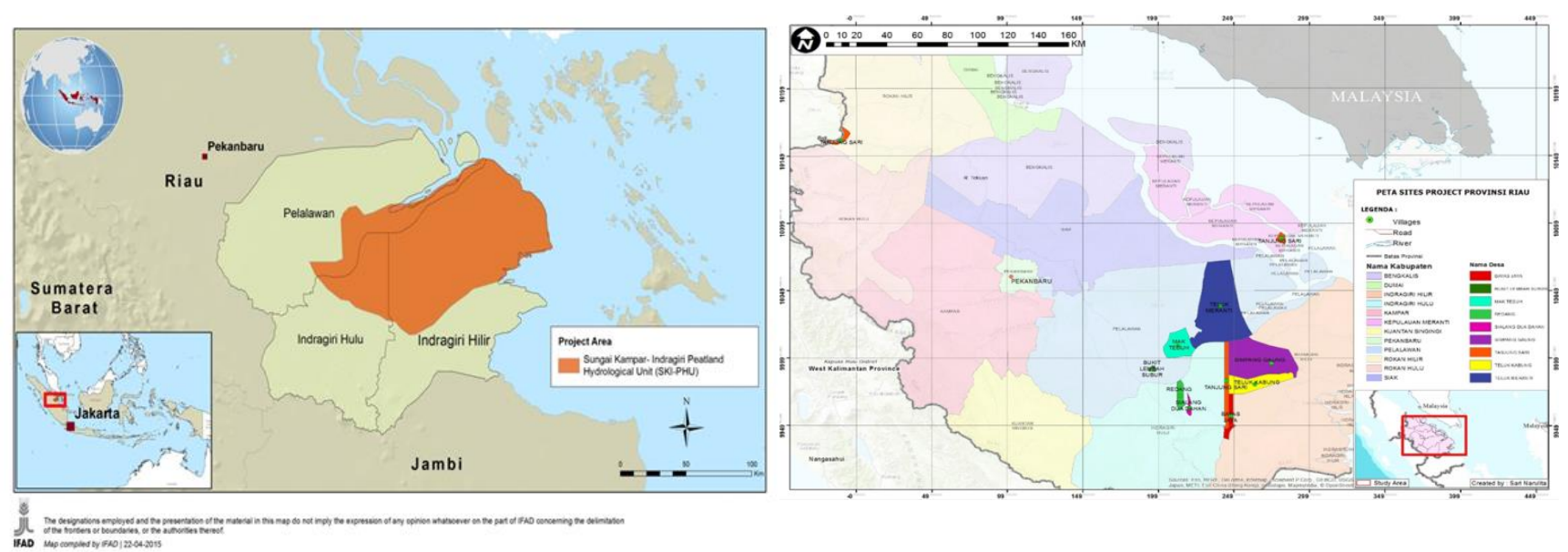

Figure 1. Location of study site in Riau, Indonesia. Left figure indicating 3 districts as research site in Riau; Right figure indicating village sites

Table 1. List of activities/tasks according to the classes of gender roles

\begin{tabular}{llll}
\hline I. Productive & II. Reproductive & III. Community role & IV. Benefit and Asset \\
\hline Land clearing & Fetching water & Participation in social activity & Land ownership \\
Applying herbicides & Collecting fuel-wood & Membership/participation in & House ownership \\
Applying pesticides & Preparing meals & Vehicle ownership \\
Feeding livestock & Caring for children & & Agriculture tools ownership \\
Fertilizer application & Caring for the sick & & Agricultural-income management \\
Harvesting & Cleaning the home & & Non - agricultural income \\
Planting crops & House repairing & management \\
Planting trees & & \\
Producing tree seedlings & & \\
Pruning trees & & \\
Rubber tapping & & \\
Selling (non-rice) crops & & & \\
Selling agroforestry products & & & \\
Selling rice & & \\
Transporting crops & & & \\
Watering/irrigation & & & \\
Weeding & & & \\
\hline Notes: Adopted from Harvard Analytical Framework & &
\end{tabular}

Table 2. Number of respondents in each village

\begin{tabular}{lc}
\hline Village & Number of sample households \\
\hline Bayas Jaya & 32 \\
Simpang Gaung & 34 \\
Teluk Kabung & 29 \\
Redang & 31 \\
Sialang Dua Dahan & 32 \\
Tanjung Sari & 31 \\
Teluk Meranti & 32 \\
Total & 221 \\
\hline
\end{tabular}

A total of 221 households were selected in the 7 villages, resulting in a stratified random sample. During the interview, the information of each household mostly provided by men $(83 \%)$. The rest are provided by women as the head of household was absent or widow family. Table 2 presents the number of sample households in each village.

\section{Data analysis}

The data were analyzed descriptively accumulating the percentage distribution of gender roles (man only, woman only and joint). Descriptive data analysis, derived from the results of the FGDs and KIIs, were mainly used to interpret and support household-quantitative data.

A correlation analysis was done to answer which households were more gender equitable. Based on the hypothesis that gender equity would be more apparent in the better off households, a scatterplot was made between gender role distribution and level of household welfare. The analysis procedure was as follows:

Categorizing household welfare. The welfare level is indexed on a scale of 1 to 5 , in with 1 indicating a very poor household, $2=$ poor, $3=$ moderate; $4=$ rich, and 5=very rich. The determination of the index was based on household income data that were collected during the interviews. The range of household-income was between IDR 300.000 and IDR 200.000.000 per month. 
Categorizing of gender equity. For gender equity, we used the gender equity index (GEI). This index consists of three categories, namely positive (GEI $>1$ ); balanced $(\mathrm{GEO}=0)$, and negative $(\mathrm{GEI}<0)$. A positive gender equity index means that the male role is more dominant than the female role; GEI $=0$ represents a balanced role between men and women; while, GEI $<0$ represents a context in which women are more dominant than men. The scale from 0 to 1 represents the value of dominance of each gender.

Scatterplot of welfare index and gender equity index. After attributing each respondent household with a welfare and gender role equity index, we plotted the position of every single household based on both index values in the matrix $\mathrm{x}$ and $\mathrm{y} . \mathrm{X}$ for welfare index, and $\mathrm{Y}$ for GEI (Figure 8).

\section{RESULTS AND DISCUSSION}

In general, the results of this study present a profile of gender roles that apply to peatland-based communities in Riau Province. The role of men is considered dominant in the economic aspects of production and ownership of household assets. Whereas women have a significant role in domestic matters, as well as her significant role in social life and community organizations. This result is in line with Li (2015) who stated that married women and men are understood to have distinct but complementary roles.

Based on in-depth interviews with community leaders, the gender role division is not an urgent thing to be debated. The roles appear to have been considered fair and acceptable by both parties. The community adheres to the principle that women in Malay have a respectable position. Malay ancestors expressed it thus: The beauty of the sky is because there is the moon; the beauty of the earth is because there are trees; the beauty of the sea is because of fish, and the beauty of the nation is because of women (Efendi 2007).

This study presents a detailed profile of gender roles within an Islamic-Malay background as documentation of our findings from the field. Gender roles were found to vary in each category of reproductive-domestic, economyproductive, community role, benefit and assets (Figure 2). The reproductive-domestic is dominated by women as it is related to taking care of children, cooking and other domestic matters. The economic-productive activities (agricultural activities) is dominated by men for about $62.3 \%$, with $36 \%$ as collaboration between male and female contributions. Community roles are more gender balanced as around $50 \%$ is contributed jointly by men and women. On the other hand, men tend to be more dominant in benefit and asset ownership.

The next section discusses in more detail the gender role distribution in each aspect, as well as the correlation between wealth and gender equity in each household.

\section{Gender role in agriculture activity}

Through FGDs, it was identified agriculture commodities in each village (Table 3 ). The community practice sedentary agriculture with the most cultivated plantations are oil palm (Elaeis guineensis Jacq) and rubber (Hevea brasiliensis). Oil palm and rubber are cultivated in all villages as a very important source of income. Coconuts are cultivated in Simpang Gaung and Teluk Kabung as alternative main income. The commonly cultivated agricultural commodities are paddy (Oryza sativa), corn (Zea mays) and various vegetables, such as chili (Capsicum annuum), pineapple (Ananas comosus), kale (Ipomoea aquatica), spinach (Spinacia oleracea), and eggplant (Solanum melongena).

Gender role distribution in agricultural activity is specified according to the sequence of activities and consists of: (i) land preparation; (ii) planting; (iii) weeding; (iv) applying fertilizer; (v) harvesting; (vi) selling; (vii) price negotiations; and (viii) determination of plant species (Figure 3).

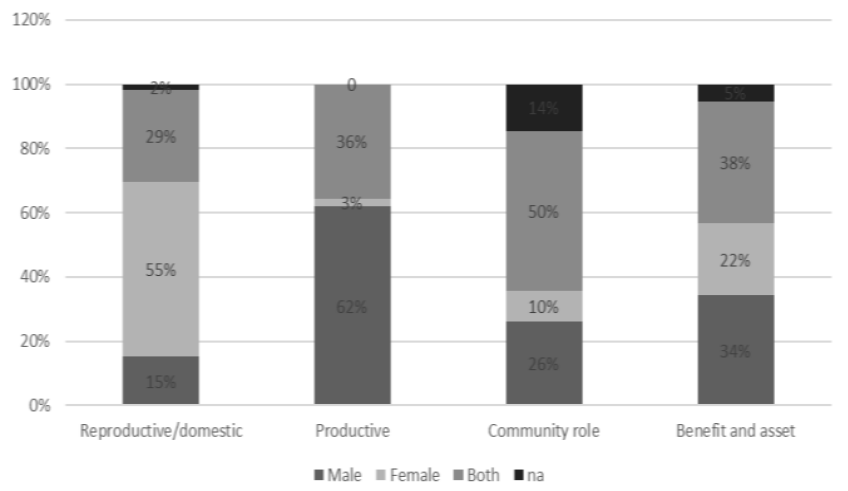

Figure 2. Gender role on the aspect of reproductive-domestic, economy-productive, community role and benefit asset

Table 3. Key commodities in each village

\begin{tabular}{|c|c|c|c|}
\hline \multirow{2}{*}{ Village } & \multicolumn{3}{|c|}{ Agriculture commodities } \\
\hline & Oil palm & Rubber & Others \\
\hline Bayas Jaya & + & + & Pineapple, paddy \\
\hline Simpang Gaung & + & - & Coconut, betel nut \\
\hline Teluk Kabung & + & - & Coconut, betel nut \\
\hline Redang & + & + & $\begin{array}{l}\text { Sweetcorn, spinach, } \\
\text { chili, eggplant, kale }\end{array}$ \\
\hline $\begin{array}{l}\text { Sialang Dua } \\
\text { Dahan }\end{array}$ & + & + & $\begin{array}{l}\text { Sweetcorn, spinach, } \\
\text { chili, eggplant, kale }\end{array}$ \\
\hline Tanjung Sari & + & + & $\begin{array}{l}\text { paddy, pineapple, chili, } \\
\text { eggplant, kale }\end{array}$ \\
\hline Teluk Meranti & + & + & $\begin{array}{l}\text { Sweetcorn, pineapple, } \\
\text { paddy }\end{array}$ \\
\hline
\end{tabular}

Note: Primary data from baseline study Haze Free Sustainable Livelihood Project 


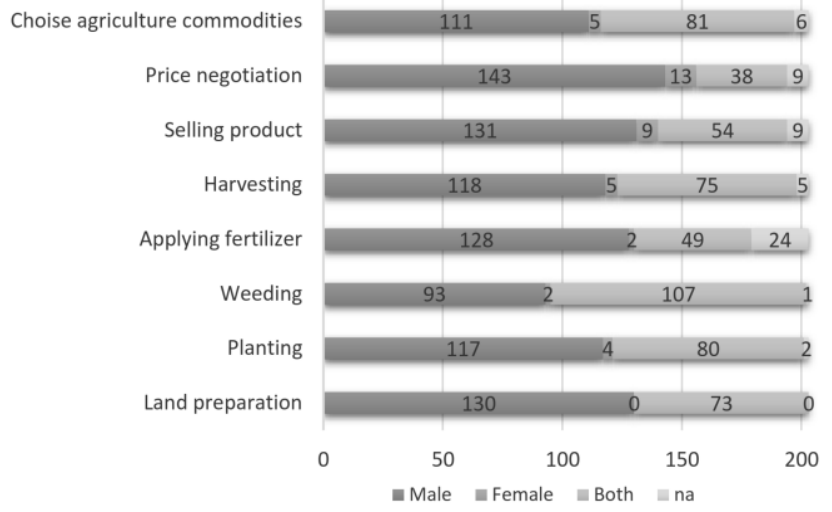

Figure 3. Gender distribution role on agriculture activities

Land preparation activities consist of cutting down trees or shrubs, hoeing, or burning, so the land is ready for planting. Land preparation activities are mostly carried out by men. Respondents who answered land preparation were done only by man amounted to $59 \%$, and jointly done by men and women $(33 \%)$. Land preparation has never routinely been done by women alone. This finding is in line with a recent study on gender roles in a wet farming system in Java (Partasmita et al. 2019). Every time women were involved in land clearing activities she always supported a man's job and responsibility. Moreover, land clearing in the peatland is now more restricted since the implementation of the zero burning policy (Murniati and Suharti 2018).

In planting activities, $53 \%$ of respondents stated that growing plants was only done by men, $2 \%$ by women only, $36 \%$ were carried out together. This profile of role distribution is similar to applying fertilizer activities, in which respondent households reported fertilization to be by men only; by women only; and jointly, respectively (58\%, $1 \%, 22 \%)$. Distribution of gender roles in harvesting activities, sale of yields and price negotiations are dominated by men as is indicated by the response from households of 53\% (harvest); $59 \%$ (sale of crops); and $65 \%$ (price negotiation) who reported that the activity is carried out only by men. This result is slightly different in weeding, where women are more involved together with men $(48 \%)$ compared to men only $(42 \%)$.

An important aspect to be expressed in the distribution of gender roles is decision-making at the household level in terms of determining plants to be cultivated on the land. Data from the interviews show that there is still a dominance of men in choosing plant species, $50 \%$ of the respondents interviewed. Only $37 \%$ of households stated that this decision was taken jointly by men and women. However, this shows that women also have a role in making decisions. Interviews with key informants as well as the FGDs confirmed that the current conditions had given a role for women to discuss family decisions. This profile provides an overview of how women's groups have an opportunity to determine actions at the household level.

This result is a confirmation of the dominant role of men in agricultural activities. Riau's people expressed the belief that men were the heads of households who assumed responsibility as breadwinners. Meanwhile, the role of women was described as more responsible for managing activities at home. Manfre and Rubin (2012) stated that the division of gender roles is influenced by cultural, economic, and political situations. Construction of women in each culture is different, because culture refers to learned behavior. Culture consists of general values held in a group of people; is a set of norms, habits, values, and assumptions that direct the behavior of the group. Culture also influences values and beliefs (Mangunsong 2004).

\section{Gender role in domestic activity}

Domestic activities are divided into 7 aspects, namely: (i) fulfillment of water needs; (ii) fulfillment of energy needs; (iii) food preparation; (iv) childcare; (v) caring for the sick family members; (vi) house cleaning; and (vii) house repairing. The study shows that the domestic aspect is almost dominated by women (Figure 4). All domestic activities are dominantly played by women, but house repairing has remained as men responsibility. Riau Malay culture is always referring to Islamic ideology, for this reason, Malay women in their behavior mainly are guided by this norm (Maleha 1986). Basically, there is no single rule that limits the differences in status and position between men and women in Malay society in Riau (Agustiar 2014).

This finding is also relevant to what happened in the Java culture (Putri and Lestari 2005). Even though, Javanese agricultural community started to be more flexible in term of who should responsible for domestic affairs, implying that there is no longer a strict separation task between men and women in doing domestic activity. As recently, women are also provided greater contribution in economic-productive activity as indicated in the agricultural community in Kumalasari et al. (2018); Hermanto (2018). Study by Elmhirst et al. (2016) in Dayak Kenyah community is also supporting this condition, that indicating no singular nonjudgmental about either sex performing tasks that are most commonly undertaken by the other.

\section{Gender role in social community activities}

Contrary to many people's assumptions, with regard to social activities, the roles of men and women look more balanced. Some have argued that women do not actively participate in social activities or in group membership. The results showed that half of the respondent couples shared a balanced role between men and women in participation in social activities and group membership. More than half of household respondents stated that membership in community group organizations and participation in social activities were carried out by both men and women. Only $26 \%$ of households stated that this activity was followed by men without involving women. In general, this condition occurs if the couple still has small children who need fulltime care. However, there were also $10 \%$ of households who stated that this activity was followed by women only. This condition occurs mainly in households headed by women, because their husbands have passed away or work outside the village area. 


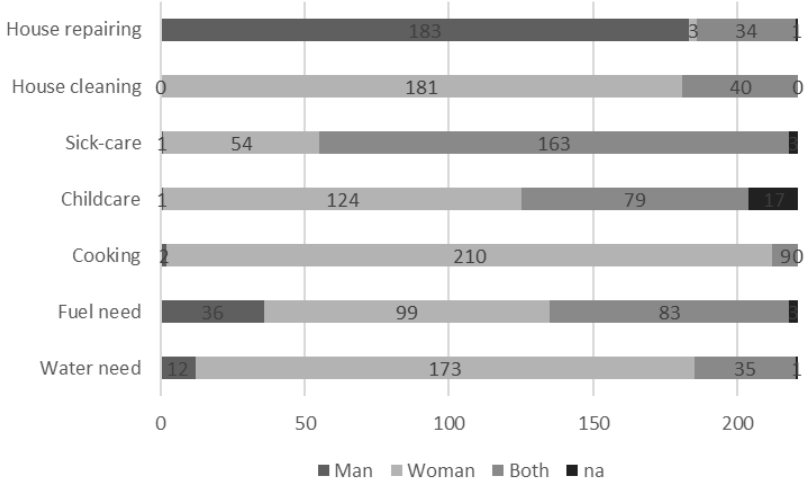

Figure 4. Gender role distribution on domestic activities

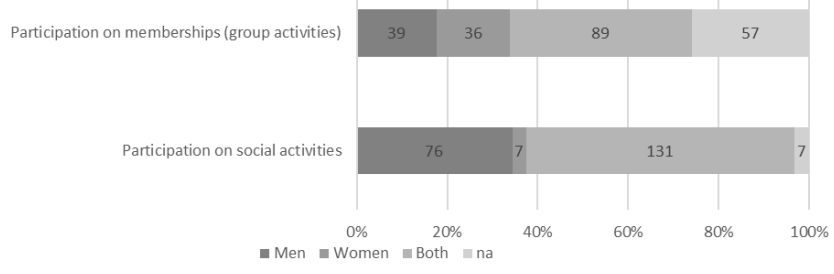

Figure 5. Participation in social activities and group membership by men and women

The assumption held up to now is that the women are not actively involved in community activities. This finding can be a counter to the negative stereotypes of Malay women who are portrayed as self-satisfied, lacking in initiative, inefficient in doing things, lacking in respect for time, lacking imagination and less persistent in trying (Rahman 1971). This negative stereotype does not only apply to Malay women's groups, but the Malay community. Some of the things that characterize the Malay community are: (i) the low ability to compete, (ii) high poverty rates, (iii) lack of quality food sources, due to peatland which blocks rice plants from flourishing, (iv) Satisfaction with results that have been achieved and family groups that are tightly bound so that it is difficult to develop, and (v) Patterns of education that do not lead them to become trained personnel. This negative stereotype may describe the facts of its time, at least 4 decades ago or even far before (Agustiar 2014). However, with the changing times and various quick-paced changes, there has also been a change in the character of society. Advanced information technology, television, radio, newspapers, and personal communication devices (devices) also influenced people's thinking patterns and shifted gender issues in the view of Malay culture (Agustiar 2014). This finding is quite encouraging because women's participation, in general, was assumed to be very limited.

Furthermore, Agustiar (2014) identified education as one of the factors changing gender roles in Malay society. A famous proverb "No matter how high a woman's education level, she will end up in the kitchen" is now almost not applicable in everyday life. This is because it is contradicted by the reality of the change in social life, which shows that women who are educated can also play a role in various jobs, including those previously only done by men. Today's women do not just take care of the kitchen as a symbol of the household. Women who are teachers and educators today may sometimes be admired far more than men. Men and women from various family background seemed to compete to fulfill development goals and earn a living for family life. This can be seen from how many Malay women today have succeeded in various fields of work and business, both civil servants and the private sector; besides that, there are also many Malay future generations who have benefitted from a high level of education in various fields. This finding is in line with study result of "The Balance of Power in Household Decision-Making" in Sulawesi community (Carol et al. 2016), and in Dayak Kenya community (Colfer 2008).

\section{Gender roles in asset and benefit sharing}

Ownership of land is dominated by men, as $62 \%$ of the households mentioned that the land formally belongs to men, only $4 \%$ of land ownership is held by women. Joint ownership of land between men and women is represented by $15 \%$ of households (Figure 6 ). The same pattern occurs in the rights of vehicle assets and agricultural equipment. Men are more dominant in controlling the rights to these two assets, $69 \%$ each for vehicle assets and 58\% for agricultural equipment. Women only own $5 \%$ of vehicles and $1 \%$ of agricultural tools. Joint ownership of vehicles is stated by $13 \%$ of respondents and $11 \%$ for ownership of agricultural equipment.

Our findings as shown by Figure 6 indicated that right on land was dominated by men. The FGDs and KIIs revealed that the tenure on land could be originated from two processes. At the transmigrate villages (Bayas Jaya and Tanjungsari) land rights were given by the central government. Government opened the forests, cleared the land and distributed to transmigrate head of households (men). In the rest of the villages, right on land was originated from forest clearing activities done by groups of household representative (men). Land rights were distributed by group leaders who coordinated the forest clearing. Land right by next generations obtains from their parents which mainly following the Islamic inheritance system, where men occupy twice the right as compared to women.

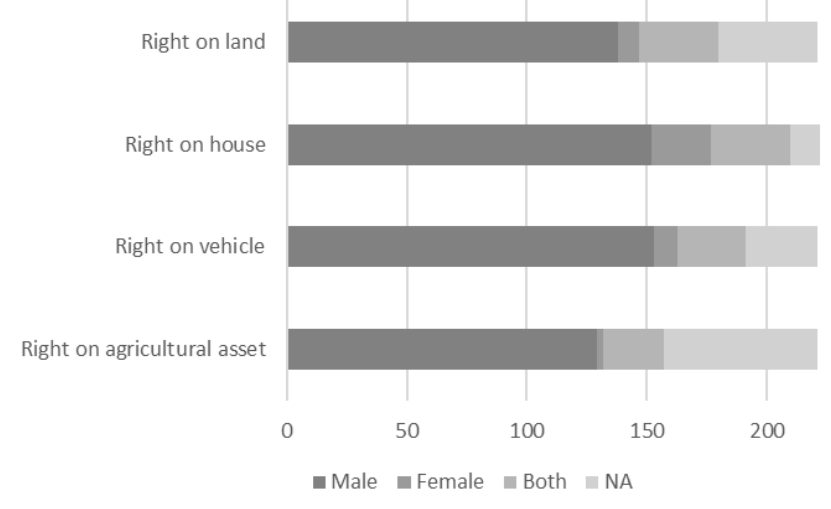

Figure 6. Household asset distribution between men and women 
Goetz and Jenkins (2018) examined recent scholars which emphasize shifting on gender property relations due to the influence of stronger women's movements. The changes also respond to several decades of globalizing human rights awareness among which tenure security is slowly finding its place as a human right in all circumstances (Wily and Liz 2018). Globalized connectivity among countries and their populations means that there is more popular knowledge as to changes in other countries; this also plays a role (Wily and Liz 2018). Meanwhile, gender issues cannot be separated from the context in which the community is located. As noted above, gender refers to the cultural, economic and political features associated with being men or women (Manfre and Rubin 2012); gender manifests itself as qualities and behaviors considered appropriate by society for men and women (Groverman and Gurung 2001).

However, sometimes there is some differentiation in which they have even distribution between family members on ownership of agricultural land, houses, vehicles or agricultural production equipment as indicated by $13 \%$ of households. The result is slightly different from those expressed by Akter et al. (2017) who examines gender roles in 4 Asian countries (Philippines, Thailand, Myanmar, and Indonesia) and in Latin America (Deere and León 2003) and the USA (Deere and Doss 2006). Using the theoretical framework recommended by the Women's Empowerment in Agriculture Index (WEAI), 37 FGDs were conducted involving 290 women farmers in the four countries. Akter et al. (2017) mentioned that women have equal access to men in terms of access to production resources in the form of land and other agricultural production inputs. Akter further emphasized that their findings refute narratives that emphasize men domination in terms of ownership of agricultural assets and resources.

Even though almost all household assets are held by men in our research, women's groups also have considerable authority in managing income. On average, income from agricultural products and wages are managed by men only in $14 \%$ and $17 \%$ respondents; while those managed by women only are carried out in $48 \%$ and $37 \%$ of household respondents. The number of households that manage income together is $32 \%$ (Figure 7).

With regard to managing household income, this result is in line with Akter et al. (2017) who found that women have greater control rights than men. The results of the research showed evidence of a wide range of rights for women's groups in managing family income. This condition is influenced by a community culture that emphasizes women as more thorough and detailed in managing family finances. Elmhirst (2000) argued that in Indonesia, as well as in other Asian countries, gender resource use and control are blurred, she used the terms fluidity and gender ambiguity. This differs from the cases of Africa and South Asia where the roles of women and men in natural resource management are quite clearly segregated.

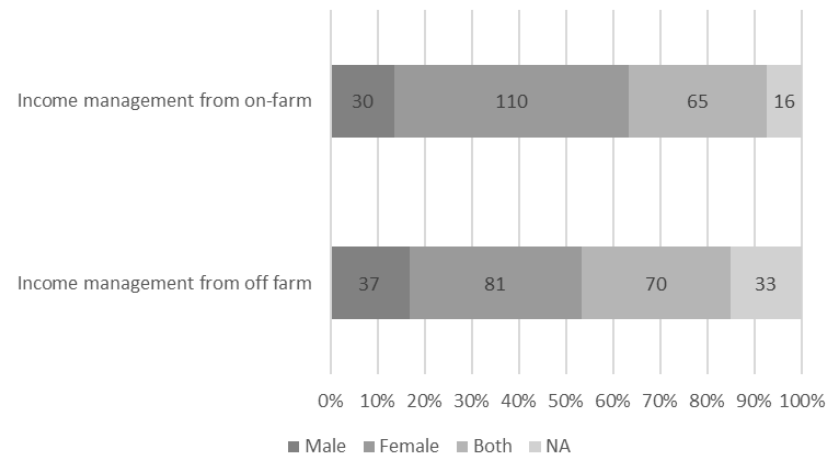

Figure 7 Gender distribution role on benefit from income

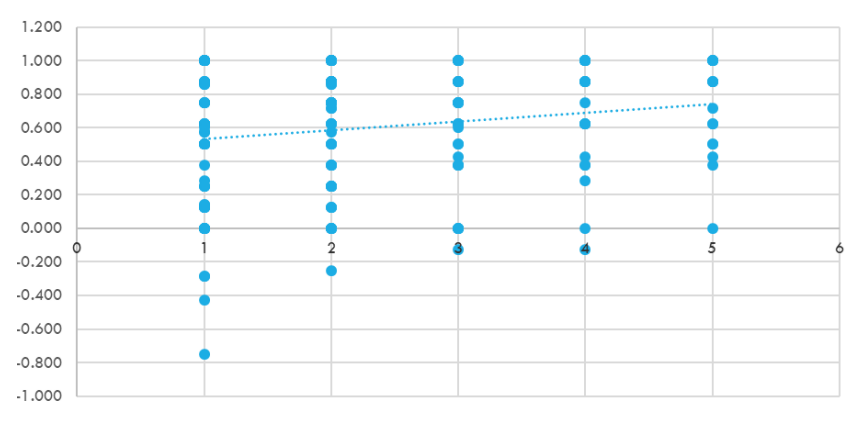

Figure 8. Correlation between gender equity index and household welfare level. Notes: $\mathrm{X}:$ welfare level $(1:$ very poor; $2:$ poor; 3 : middle; $4:$ rich;5 : very rich) and $\mathrm{Y}:$ gender equity index $(>0$ : man domination; 0 : balance gender role; $0<$ : woman domination

\section{Gender equity on different level of household welfare}

Analysis of correlation was carried out to understand the relationship between level of household welfare and gender equity index. Each of 221 households was categorized in welfare level based on income. Gender equity index represents how dominant women or men in agricultural activities that cover land preparation, planting, weeding, fertilization, harvesting, selling products, price negotiations, and choosing the plant species. Positive values represent men domination in agricultural activities, and vice versa the negative values represent women domination. The level of household welfare and gender equity index values are plotted and presented in Figure 8 .

Figure 8 shows a positive relationship between gender equity index in agriculture and level of household welfare. Consistently the role of women decreases with increasing levels of household welfare. The figure indicates that on more welfare household, gender roles on agriculture activities tend to be men dominance. The analysis also tells us that role of women in agricultural activities is more prevalence at poor families. In poor households, male and female laborers are jointly devoted to farming activities. They do not have enough capital resources other than labor, so the participation of women in farming activities is an important contribution to the income of poor families. In contrast to richer households, the role of men in agricultural activities becomes more dominant. In richer 
households, women no longer devote their physical labor directly to farming activities, but they play more roles in managing family finances, including the recruiting paid men labors. This was confirmed by the collected information from the KIIs. The results indicate that in prosperous families, the roles of women in agricultural activities were transformed into more managerial activities of household resources.

This case study of gender role distribution from the peatland-based community in Riau Province of Indonesia concludes several points. First, men are more dominant in the economic or productive activities, while women have more significant roles in domestic activities. The productive activities include decision in selecting cultivated species (trees or crops), preparing the land for farming, planting the seedlings, tending the crops or trees, fertilizing, harvesting and selling agricultural products, including negotiations with traders. The domestic business comprises activities such as cooking, taking care of the kids and cleaning house, fulfilling the needs for energy and water. The only activities that are dominated by men in domestic business are house repairing. This result confirms the existing finding of men domination based on the socialcultural context. In social activities, the peatland-based community shows more equal roles of both men and women. Second, men are significantly dominant on asset ownership for land, agriculture equipment, house, and vehicle. In contrast, it was showed that women have more roles in managing income that originated from both agriculture and non-agriculture activities. Third, gender role tends to be equal in agriculture activities of poor households. When the households become richer, the role of women in agriculture activities decreasing, but their roles were transformed from physical involvement into income management activities, such as in recruiting men labors to work on their lands.

The fifth sustainable development goals mandate gender equality (gender equality) in all aspects including management of natural resources and the environment. As suggested by Colfer et al. (2013, 2015), three fundamental indicators should be considered in development programs for community in managing peatland sustainably, namely gender and governance on peatland management, a combination of production and other more sensitive issues central to women's lives, and intra-household decisionmaking. The forms of development interventions need to be targeted for both men and women. For example, training activities on processing peatlands to increase productivity, should not only targeted at men, but also women, especially from lower economic families. For families who are relatively more prosperous, the intervention can be directed to develop entrepreneurship, such as assisting households in mastering knowledge and skill on processing value-added agricultural products.

As concluded in general agriculture research (Elizabeth 2016), this study supports that double roles of women in income generating activities play important contribution to households income. Women potentials, either as a housewife or as an individual of agricultural worker is an important factor to determine the success of gender mainstreaming strategy. Community development interventions should truly consider women involvement in designing the interventions, such as in developing innovative technology, protecting the worker women, improving approach in delivering training and extension activities, and in the enhancement of regulations.

\section{ACKNOWLEDGEMENTS}

We are grateful to the IFAD (International Fund for Agricultural Development) for funding support of this project. Thanks, are also due to all stakeholders involved in the process of data collection such as enumerators under Dr. Eno Suwarno's supervision from University of Lancang Kuning Riau, the villagers in all project sites, local governments as well as other parties supporting the project research. Thanks also are due to Chris Beadle for invaluable input during the drafting process of this manuscript.

\section{REFERENCES}

Agustiar. 2014. Gender dalam Budaya Puak Melayu Riau. Jurnal Ilmu Budaya 1 (1): 67-75. [Indonesian]

Arwida SD, Maharani CD, Basnet BS, Yang AL, Resosudarmo DP, Wong GY, Brockhaus M, Madhavan P. 2016. Gender in Forestry and REDD+ in Indonesia. Center for International Forestry Research (CIFOR), Bogor.

Broeckhoven N, Cliquet N. 2015. Gender and ecological restoration: Time to connect the dots. Restor Ecol 23 (6): 729-36.

Budidarsono S, Susanti A, Zoomers A. 2013. Oil palm plantations in Indonesia: The implications for migration, settlement/resettlement and local economic development. In: Z Fang (ed.) Biofuels Economy, Environment and Sustainability. InTech, Rijeka, Croatia.

Colfer CJP, Catacutan J, Naz F. 2015. Introduction: contributions and gaps in gender and agroforestry. Intl For Rev 17 (Suppl. 4): 1-10.

Colfer CJP, 2008. The longhouse of the tarsier: Changing landscapes, gender and well being in Borneo. Borneo Research Council Monograph Series. Phillips, USA

Colfer CJP, Achdiawan R, Roshetko JM, Mulyoutami E, Yuliani EL, Mulyana A, Moeliono M, Adnan H, and Erni. 2015. The balance of power in household decision-making: Encouraging news on gender in Southern Sulawesi. World Dev 76: 147-164.

Colfer CJP, Achdiawan A, Adnan H, Ern, E. Yuliania L, Balang and LepMil. 2013. Gender and natural resource governance indicators: A need to assess and address 'sensitive and taboo' topics. For Trees Livelihoods 22 (3-4): 143-155.

Colfer CJP, Achdiawan A, Adnan H, Moeliono M, Mulyana A, Mulyoutami E, Roshetko JR, Yuliani EL, Balang, and LepMil. 2015. Preparing the ground for better landscape governance: Gendered realities in Southern Sulawesi. For Trees Livelihoods 24 (1): 59-83.

Deere CD, Doss CR. 2006. The gender asset gap: what do we know and why does it matter? Feminist Econ, 12 (1-2): 1-50.

Deere CD, León M, 2003. The gender asset gap: land in Latin America. World Devel 31 (6): 925-947.

DJP. 2015. Statistik Perkebunan Indonesia; kelapa sawit 2014-2016. Direktorat Jenderal Perkebunan, Kementerian Pertanian, Jakarta. [Indonesian]

Djoudi H, Locatelli B, Vaast C, Asher K, Brockhaus M, Sijapati BB. 2016. Beyond dichotomies: gender and intersecting inequalities in climate change studies. Ambio 45 (3): 248-262.

Efendi T. 2001. Gender dalam adat dan budaya melayu. Makalah disampaikan pada pertemuan daerah rencana aksi penghapusan kekerasan terhadap perempuan. Pekanbaru. [Indonesian]

Elias M, Elmirst R, Ibraeva G, Basnett BS, Ablezova M, Siscawati M. 2018. Understanding gendered innovation processes in forest-based landscapes: Case studies from Indonesia and Kyrgyz Republic. 
GENNOVATE Report to the CGIAR Research Programs on Forests, Trees and Agroforestry (FTA). Bioversity International, Rome.

Elizabeth R. 2016. Pemberdayaan wanita mendukung strategi gender mainstreaming dalam kebijakan pembangunan pertanian di perdesaan. Forum Penelitian Agro Ekonomi, 25 (2): 126-135. [Indonesian]

Elmhirst R, Siscawati M, Carol CJP. 2016. Revisiting gender and forestry in Long Segar, East Kalimantan, Indonesia. In: Carol CJP, Basnett BS, Elia M. Gender and Forest: Climate Change, Tenure, Value Chains, and Emerging Issues. Earthscan. Routledge, London.

FAO. 2009. Bridging the Gap: FAO Programme for Gender Equality in Agriculture and Rural Development. FAO, Rome.

FAO. 2016. Gender and Resilience Brief Resilience Promising Practice Unleashing the Potential of Women and Girls to Become Agents of Resilience. FAO, Rome.

Goetz, Marie A, Jenkins R. 2018. Feminist activism and the politics of reform: When and why do states respond to demands for gender equality policies? Dev Change 49 (3): 714-734.

Gunawan H. 2018. Indonesian peatland functions: Initiated peatland restoration and responsible management of peatland for the benefit of local community, case study in Riau and West Kalimantan Provinces. In: Environmental Resources Use and Challenges in Contemporary Southeast Asia. Springer, Singapore.

Hannan C. 2000. From Concept to Action: Gender Mainstreaming in Operational Activities. UNDP, New York.

Hergoualc'h K, Carmenta R, Atmadja S, Martius S, Murdiyarso D, and Purnomo H. 2018. Managing Peatlands in Indonesia: Challenges and Opportunities for Local and Global Communities. Center for International Forestry Research (CIFOR), Bogor.

Hermanto D. 2018. Analisis kontribusi pendapatan ibu rumah tangga pemetik jambu biji pada PT. Nusantara Tropical Farm (NTF) terhadap pendapatan keluarga di Kabupaten Lampung Timur. Media Ekonomi 18 (2): 82-94. [Indonesian]

Kandel TP, Elsgaard L, Laerke PE. 2013. Measurement and modelling of $\mathrm{CO}_{2}$ flux from a drained fen peatland cultivated with reed canary grass and spring barley. GCB Bioenerg 5 (5): 548-561.

Kasher A, Varley G. 2018. Gender in the jungle: A critical assessment of women and gender in current (2014-2016) forestry research. International For Rev 20 (2): 149-159.

Kuehnast BY, Robertson D, Connolly D, Hewitt J, Lancaster I, Milofsky A, Rosarie SS, Tucci, Zanchelli M, 2018. Gender Inclusive Framework and Theory: A Guide for Turning Theory into Practice. United States Institute of Peace. Washington, DC.

Koglo YS, Gaiser T, Agyare WA, Sogbedji JM, Kouami K. 2019. Implications of some major human-induced activities on forest cover using extended change matrix quantity and intensity analysis based on historical landsat data from the Kloto District, Togo. Ecol Indicat 96: 628-34.

Kumalasari B, Herawati T, Simanjuntak M. 2018. Relasi gender, tekanan ekonomi, manajemen keuangan, strategi nafkah, dan kualitas hidup pada keluarga nelayan. Jurnal Ilmu Keluarga dan Konsumen 11 (2): 108-119. [Indonesian]

Li TM, 2015. Social Impacts of Oil Palm in Indonesia: A Gendered Perspective from West Kalimantan. Center for International Forestry Research (CIFOR), Bogor.

Maftuah E, Norr M, Hartatik W, Nursyamsi D. 2015. Pengelolaan dan Produktivitas Lahan Gambut Untuk Berbagai Komoditas Tanaman. Jurnal Litbang Tanaman Pertanian (2014): 131-162. [Indonesian]

Maleha A. 1976. Peranan Sultan Syarif Kasim II dalam Mempertahankan Proklamasi Kemerdekaan Republik Indonesia di Siak Indrapura. Pekanbaru. [Indonesian]

Manfre C, Rubin D. 2012. Integrating Gender into Forestry Research: A Guide for CIFOR Scientists and Programme Administrators. Center for International Forestry Research (CIFOR), Bogor.

Mangunsong F. 2009. Faktor intrapersonal, interpersonal, dan kultural pendukung efektivitas kepemimpinan perempuan pengusaha dari empat kelompok etnis di Indonesia. Makara Sosial Humaniora 13 (1): : 19-28. [Indonesian]

McDermott M, Mahanty S, Schreckenberg K. 2013. Examining equity: A multidimensional framework for assessing equity in payments for ecosystem services. Environ Sci Pol 33: 416-427.
Mulyoutami E, Catacutan D, Martini E, Khususiyah N, Janudianto, Villamor GB, Van Noordwijk M. 2013. Gender roles in land use and value chains (GRoLUV). Negotiation-support toolkit for learning landscapes. In: Van Noordwijk M, Luisiana B, Beria L, Dewi D, Wulandari D (eds.). Negotiation-Support Toolkit for Learning Landscapes. World Agroforestry Center (ICRAF), Bogor.

Murniati, Suharti S. 2018. Towards zero burning peatland preparation: Incentive scheme and stakeholders role. Biodiversitas 19 (4): 13961405

Na'im A, Syaputra H. 2011. Kewarganegaraan, Suku Bangsa, Agama, dan Bahasa Sehari-hari Penduduk Indonesia: Hasil Sensus Penduduk 2010. Badan Pusat Statistik, Jakarta. [Indonesian]

Noble A, Palmer SM, Glaves DJ, Crowle A, Brown LE, Holden J. 2018. Prescribed burning, atmospheric pollution and grazing effects on peatland vegetation composition. J Appl Ecol 55 (2): 559-569.

Parish FS, Charman A, Joosten D, Minayeva H, Silvius T, Stringer M. 2008. Assessment on Peatlands, Biodiversity and Climate Change: Main Report. Global Environment Centre, Kuala Lumpur \& Wetlands International, Wageningen.

Partasasmita R, Iskandar BS, Nuraeni S, Johan I. 2019. Impact of the green revolution on the gender's role in wet rice farming: A case study in Karangwangi Village, Cianjur District, West Java, Indonesia. Biodiversitas 20 (1): 23-36.

Prasetyo B, Chikmawati T, Walujo EB, Amzu E. 2018. Ethnoecology: The traditional landscape of Osing Tribe in Banyuwangi, Indonesia. Biodiversitas 19 (6): 2003-9.

Putri DPK, Lestari S. 2005. Pembagian peran dalam rumah tangga pasangan suami istri jawa. Jurnal Penelitian Humaniora 16 (1): 72-85. [Indonesian]

Razavi S, Miller C. 1995. From WID to GAD: Conceptual Shifts in the Women and Development Discourse. United Nations Research Institute for Social Development, Geneva.

Recoftc. 2015. Mainstreaming Gender into Forest Policies in Asia and the Pacific. FAO \& RECOFTC, Bangkok.

Renou-Wilson F. 2018. Peatlands. In: Creamer R, O’Sullivan L (eds) The Soils of Ireland. Springer International Publishing, Cham, Switzerland.

Santika T, Meijaard E, Budiharta S, Law EA, Kusworo A, Hutabarat JA, Indrawan TP. 2017. Community forest management in Indonesia: Avoided deforestation in the context of anthropogenic and climate complexities. Global Environ Change 46 (2017): 60-71.

Schoneveld GC, Andrianto A, Van Der Haar S. 2018. Modeling peat-and forestland conversion by oil palm smallholders in Indonesian Borneo. Environ Res Lett 14: 014006. DOI: 10.1088/1748-9326/aaf044.

Schroeder H., McDermott C. 2014. Beyond carbon: enabling justice and equity in REDD+ across levels of governance. Ecol Soc 19 (1): 31.

Savi S. 2018. The palm oil market: Growth and trends. In: Rival A (ed) Achieving Sustainable Cultivation of Oil Palm: Volume 1. Burleigh Dodds Science Publishing, Cambridge, UK.

Strack M, Softa D, Bird M, Xu B. 2018. Impact of winter roads on boreal peatland carbon exchange. Global Change Biol 24 (1): 201-212.

Syah H. 2001. Islam dan keseteraan gender. Makalah disampaikan pada Pertemuan Daerah Rencana Aksi Nasional Penghapusan Kekerasan terhadap Perempuan. Pekanbaru [Indonesian]

Tooth S. 2018. The geomorphology of wetlands in drylands: Resilience, nonresilience, or ...? Geomorphology 305: 33-48.

Villamor GB, Akiefnawati R, Noordwijk MV, Desrianti F, Pradhan U. 2015. Land use change and shifts in gender roles in Central Sumatra, Indonesia. Intl For Rev 17 (S4): 61-75.

Visseren-Hamakers IJ, McDermott C, Vijge MJ, Cashore B. 2012. Tradeoffs, co-benefits and safeguards: Current debates on the breadth of REDD+. Curr Opin Environ Sustain 4 (6): 646-653.

Wily LA. 2018. Collective Land Ownership in the 21st Century: Overview of Global Trends. Land 7: 68 .

World Bank. 2014. INDO-DAPOER (Indonesia Database for Policy and Economic Research). World Bank, Washington DC.

Worrall F, Clay GD, Marrs R, Reed. 2010. Impacts of Burning Management on Peatlands. IUCN, London, UK.

Yu X, Mingju E, Sun M, Xue Z, Lu X, Jiang M, Zou Y. 2018. Wetland recreational agriculture: Balancing wetland conservation and agrodevelopment. Enviro Sci Pol 87: 11-17. 